\title{
Improving diarrhoeal and clean and healthy living behaviour (PHBS) through collaboration socio-dramatic play (Ko-Berdrama) in school age children
}

\author{
*Lita Heni Kusumawardani ${ }^{1}$, Etty Rekawati ${ }^{2}$, Poppy Fitriyani ${ }^{2}$
}

Sri Lanka Journal of Child Health, 2019; 48(3): 240-245

\begin{abstract}
Introduction: Indonesian health status is strongly influenced by clean and healthy living behaviour (PHBS or Perilaku Hidup Bersih dan Sehat). PHBS programmes should be implemented from school age so that healthy lifestyle practices can persist into adulthood. Community nurses implement play socio-dramas (Ko-Berdrama) as a method of health education in an effort to increase PHBS.
\end{abstract}

Objectives: To determine the effect of play sociodrama (Ko-Berdrama) intervention to change the knowledge, attitudes, and skills of PHBS in school age children.

Method: The design is a quasi experimental one for 8 months. The calculated sample size was 184 school age chidren. School age children 6-12 years old who had a problem of lack of PHBS based on the results of questionnaires and screening PHBS were included in the study. Community nurses used play socio-drama (Ko-Berdrama) in seven sessions over 6 months, staging each session for 20 minutes followed by 20 minutes of discussion, Data collection tool was a questionnaire consisting of variable knowledge, attitudes, and PHBS skills of school-age children. Data were analysed using the paired t-test.

Results: Results using the paired t-test of knowledge, attitude, and skills variables on schoolage children before and after Ko-Berdrama interventions were tabulated. The results showed that socio-dramatic play significantly affects

\footnotetext{
${ }^{1}$ Department of Nursing, Universitas Jenderal Soedirman, Purwokerto, Indonesia

${ }^{2}$ Faculty of Nursing Universitas Indonesia, Indonesia

*Correspondence:litahenikusumawardani@gmail.com

D. orcid.org/ 0000-0002-5293-2139

(Received on 22 October 2018: Accepted after revision on 21 December 2018)

The authors declare that there are no conflicts of interest

Personal funding was used for the project.
}

Open Access Article published under the Creative

Commons Attribution CC-BY (CC) knowledge $(\mathrm{p}=0.002)$, attitudes $(\mathrm{p}=0.005)$, and diarrhoeal prevention skills $(\mathrm{p}=0.008)$ of PHBS. Knowledge about PHBS increased from $45.1 \%$ to $61.4 \%$, the child's attitude about PHBS increased from $44.6 \%$ to $59.8 \%$ and the skills of children about PHBS increased from $42.9 \%$ to $54.9 \%$.

Conclusions: Socio-dramatic play (Ko-Berdrama) significantly increases knowledge, attitudes, and diarrhoeal prevention skills of clean and healthy living behaviour (PHBS) in school age children.

DOI: http://dx.doi.org/10.4038/sljch.v48i3.8759

(Keywords: School-age children, Ko-Berdrama, PHBS)

\section{Introduction}

Indonesian health status is strongly influenced by clean and healthy living behaviour (PHBS or Perilaku Hidup Bersih dan Sehat). Percentage of households who practised PHBS decreased from $56.5 \%$ in 2012 to $55.6 \%$ in 2013 . This is lower than the $70 \%$ target set for $2014^{1}$. Central Statistics Agency (BPS) (2016) showed the number of school-age children (6-12 years) in Indonesia was $26,504,160^{2}$. PHBS programmes should be implemented from school age so that healthy lifestyle practices can persist into adulthood ${ }^{3}$. School age children are more likely to be exposed to health problems due to biological, behavioural, and environmental risk factors ${ }^{4}$. Behaviour that can affect the health of school age children include lifestyle and personal hygiene ${ }^{5}$. Regular hand washing in children can prevent morbidity in the family and reduce school absences ${ }^{6}$.

Data on the prevalence of diarrhoea in Indonesia show that the proportion of school age children having diarrhoeal disease varies from $2 \%$ to $20 \%$ per province ${ }^{2}$. Based on data from Depok City Health Department in 2015, the hospital outpatient clinic disease pattern in age group 5-14 years was acute respiratory infection $(22 \%)$, dental disorders $(7 \%)$, fever $(6 \%)$ and diarrhoea $(5 \%)^{7}$.

The government has made efforts to change people's behaviour, including school age children and improve health through PHBS programmes. PHBS programmes that have been carried out include management of personal and health 
behaviour, making a guidebook of PHBS programme, and the campaign or socialization PHBS $^{8}$. However, the success of PHBS in the community is still not optimal for the national proportion of households with PHBS is $32.3 \%$ and there are 20 provinces that still have households with PHBS well below the national average proportion ${ }^{9}$. Therefore, it is necessary to devise a more effective method to increase PHBS.

Therapeutic play is one of the methods of health education to improve PHBS in school age children. Community nurses implement collaborative interventions play socio-drama (Ko-Berdrama) as a method of health education in an effort to increase PHBS. The results of research show that playing socio-drama with friends increases social interaction among peers ${ }^{10}$. Playing socio-drama is an important method in language development in children $^{11}$. In addition, socio-drama method of folklore enhanced the 5th grade speaking skills ${ }^{12}$.

Community nurses also include educational games in Ko-Berdrama intervention package. Educational games are played in the form of simulated practice PHBS through the 'snakes and ladders' game. PHBS themed game of 'snakes and ladders' consists of questions and a simulation props PHBS. Educational games using the game of 'snakes and ladders' effectively improved the knowledge of balanced nutrition in children of school age ${ }^{13}$. Additionally, Ejike, Oluwole, and Mogaji developed an innovative educational game 'worms and stairs' for prevention of intestinal worms in children of school age ${ }^{14}$.

Ko-Berdrama technique can be an alternative method of health education which is interactive and creative in improving PHBS. Community nurses choose socio-drama peers as actors to portray characters that describe the behaviour of clean and healthy living. Studies show that there is a significant increase in the average scores of knowledge, attitude and skills associated with PHBS before and after the peer education in the intervention group ${ }^{15}$.

\section{Objectives}

To determine the effect of play socio-drama ( $\mathrm{Ko}$ Berdrama) intervention to change the knowledge, attitudes, and skills of PHBS in school age children.

\section{Method}

The design used in this paper is a quasi experimental one for 8 months. There is a large study population, as many as 1,675 children of school age ${ }^{16}$. Based on the sample calculations and the results of the screening, a sample size of 184 children of school age was obtained. Samples were selected based on inclusion criteria that school age children 6-12 years old who have a problem of lack of PHBS based on the results of questionnaires and screening PHBS. Data collection tool in this study was a questionnaire consisting of variable knowledge, attitudes, and skills of school-age children PHBS. The questionnaire used a modification of previous studies ${ }^{19}$. Analysis of data using data processing program is displayed in percentage changes in knowledge, attitudes, and skills of PHBS.

Ko-Berdrama technique: For six months community nurses used seven sessions, staging each session for 20 minutes followed by 20 minutes of discussion. School age children first practised Ko-Berdrama around 3-5 times before performance. One group consisted of 8-10 children. The first session was on the topic of 'diarrhoeal disease'. The second session was on the topic of 'the importance of using healthy latrines and clean water sources'. The third session was on the topic of 'physical activity and fruit and vegetable consumption'. The fourth session was on the topic of 'hand washing with soap'. The fifth session was on the material practice of washing hands with soap. Sixth session consisted of race playing sociodrama hand washing practices. Seventh session consisted of reinforcement intervention by PHBS simulation using the card game of snakes and ladders. The game contains knowledge and simulation PHBS consisting of handwashing, fruit and vegetable consumption, and physical activity. After playing socio-dramas there were continued discussion groups to review the summary of the contents of drama shown earlier.

Knowledge questionnaires were in the form of dichotomous questions with right and wrong answers. A correct answer was given a value of 1 while a wrong answer was given a value of 0 . Attitude measurement instruments used a Likert scale with a range of grades 1 to 4 consisting of strongly agree (SS), agree (S), disagree (TS), and strongly disagree (STS). If in the form of a positive question (favourable statement), then SS was worth $4, \mathrm{~S}$ was worth 3 , TS was worth 2 , and STS was worth 1. If in the form of a negative question (unfavuorable statement), then SS was worth $1, \mathrm{~S}$ was worth 2, TS was worth 3, and STS was worth 4. Skill measurement instruments also used a Likert scale with a range of 1 to 4 consisting of 'always', 'often', 'sometimes', and 'never'. If in the form of a positive question (favourable statement), 'always' was worth 4, 'often' was worth 3, 'sometimes' was worth 2, and 'never' was worth 1 . If in the form of a negative question (unfavourable statement), 'always' was worth 1, 'often' was worth 2, 'sometimes' was worth 3, and 'never' was worth 4 . 


\section{Results}

The result of analysing the knowledge, attitude, and skills variables shows a significant change in the levels of each variable before and after engaging in socio-dramatic play. Alternatively, in the control group, there was no significant change in the mean values of the knowledge, attitude, and skills variables (Table 1). Distribution of knowledge, attitudes, and skills of PHBS in school age children before and after intervention is shown in Figure 1.

Table 1: Results of the paired t-test of knowledge, attitude, and skills variables on school-aged children in South Purwokerto in $2017(n=184)$

\begin{tabular}{|c|c|c|c|c|c|c|}
\hline \multirow{3}{*}{ Variable } & \multicolumn{6}{|c|}{ Intervention Group $(n=94)$} \\
\hline & \multicolumn{2}{|c|}{ Before } & \multicolumn{2}{|c|}{ After } & \multirow[b]{2}{*}{ in mean } & \multirow[b]{2}{*}{ p value } \\
\hline & Mean & SD & Mean & SD & & \\
\hline Knowledge & 7.61 & 1.326 & 9.82 & 1.540 & 2.21 & 0.002 \\
\hline Attitude & 29.66 & 2.998 & 33.61 & 3.680 & 3.95 & 0.005 \\
\hline Skills & 28.66 & 2.714 & 29.61 & 2.715 & 0.95 & 0.008 \\
\hline \multirow{3}{*}{ Variable } & \multicolumn{6}{|c|}{ Control Group $(n=90)$} \\
\hline & \multicolumn{2}{|c|}{ Before } & \multicolumn{2}{|c|}{ After } & & \\
\hline & Mean & SD & Mean & SD & Difference in mean & p value \\
\hline Knowledge & 7.89 & 1.269 & 8.08 & 1.148 & 0.19 & 0.109 \\
\hline Attitude & 28.66 & 2.485 & 29.05 & 1.610 & 0.39 & 0.129 \\
\hline Skills & 28.63 & 2.247 & 29.05 & 1.559 & 0.42 & 0.081 \\
\hline
\end{tabular}

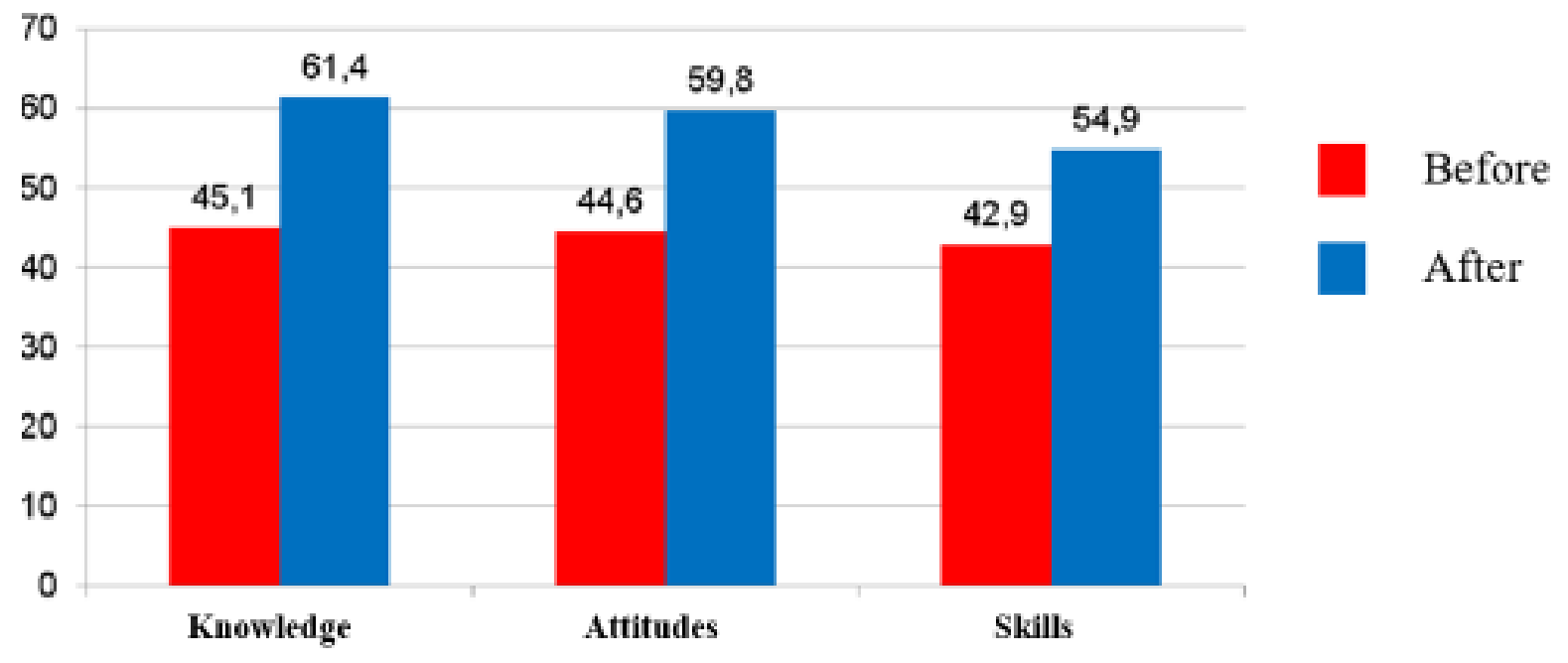

Figure 1: Distribution of knowledge, attitudes, and skills of PHBs in school aged children in the village of Curug $(n=184)$

Based on the data obtained from Figure 1, knowledge about PHBS children increased from $45.1 \%$ to $61.4 \%$, the child's attitude about PHBS increased from $44.6 \%$ to $59.8 \%$ the skills of children of PHBS increased from $42.9 \%$ to $54.9 \%$.

\section{Discussion}

Preventive and promotional efforts can be done through interactive health education engaging school-age children. The community nurse applies Ko-Berdrama technique that is learning while playing in accordance with the cognitive development of school age children. School age children begin to enter the concrete operational stage of cognitive theory of Piaget, where children with serious behaviour begin to think logically ${ }^{18}$. Increasing awareness through education with the method of dramatic relief becomes an alternative in improving knowledge ${ }^{19}$. The dramatic relief method played by school age children through socio-drama gives a deep impression to school age children as it is more subtle.

Increased knowledge after the intervention is the influence of Ko-Berdrama in relation to PHBS. One of the phases in Ko-Berdrama is the intervention phase in which children play an active role in the game socio-drama PHBS that contain material that is washing hands with soap, fruit and vegetable consumption, and physical activity. After 
that, the school-age children also had discussions regarding the material socio-dramas played before. The discussion was quite an interactive question and answer session along with the facilitator. School-age children who previously did not know about PHBS be out after being given the $\mathrm{Ko}$ Berdrama. Based on health promotion model (HPM) theory, the individual experience can be a strategy to change health behaviour through selfreflection method ${ }^{20}$. Health education with the method of Ko-Berdrama js more subtle on memory of school age children for deeper reflection process through the exploration of feelings and emotions in playing the character socio-dramas.

Changes in attitude after the intervention is a positive impact of increased knowledge. Respondents were previously not knowing to knowing about health behaviour, then making a pattern attitude change. The attitude of the respondents tend to increase after school age children realize the importance of healthy behaviour. Based on the theory of HPM, commitment to the action plan was influenced by interpersonal through peer support models ${ }^{20}$. KoBerdrama concept model of peers as a character actor in socio-dramas. In addition, the researchers also used the principle of reward and punishment during the intervention process for children of school age. The principle is quite effective in encouraging school-age children to change bad behaviour.

Skill improvement is influenced by increased knowledge and attitude of school age children. Someone who has a good attitude, has good skills as well ${ }^{21}$. The results showed an increase in healthy behaviour after health education ${ }^{22}$. Health education is one way to improve one's ability and make the right decisions with respect to health care based on experience gained. Based on HPM theory, process outcomes previously healthy behaviours are influenced by biopsychosocial processes and experiences of individuals ${ }^{20}$.

Socio-dramas play a part in this implementation using peers as a figure who plays socio-dramas. Peers as a model in providing examples of handwashing in preventing diarrhoea ${ }^{23}$. How to teach skills during the intervention process involving peers to give an example of PHBS. Individual experience can be reflected through the role of Ko-Berdrama figures. Child who plays the role as leader of diarrhoea prevention behaviours such as using a latrine, healthy water sources, hand washing with soap in running water, fruit and vegetable consumption, and physical activity. Therefore, Ko-Berdrama can be useful in influencing children towards healthy behaviours.
Teachers and parents also stated that there is an increase in healthy behaviour in school-age children. Peers also give effect to the changes PHBS like to remind each other to bring a healthy lunch, eat vegetables and fruit, exercise, and wash hands with soap. Healthy behaviours, played by peers socio-drama provides positive support to behavioural change. This shows that playing $\mathrm{Ko}$ Berdrama is able to increase PHBS in school age children.

Ko-Berdrama increases PHBS in school age children. Ko-Berdrama uses the concept of learning while playing and practising healthy behaviours directly so as to accelerate the process of educating children of school age. Ko-Berdrama can also be applied to other health themes such as the prevention of respiratory infections, intestinal worms, and skin diseases in children of school age.

\section{Conclusions}

Socio-dramatic play (Ko-Berdrama) significantly increases knowledge, attitudes, and diarrhoeal prevention skills of clean and healthy life behaviour (PHBS) in school aged children.

\section{Acknowledgements}

We thank all those who helped smoothen the specialist practice of Community Nursing, especially the Office of Depok City Health, Education Department Depok, Ministry of Religious Affairs Depok, Unit of District Health Clinics Cimanggis, Curug Urban Village, principals, teachers, students, and student's parents of SDN Curug 2, 3, 4 and MI Al Islam.

\section{References}

1. Portrait of Indonesian Education. Education Statistics 2016. Available from: https://www.bps.go.id/publication/2016/0 1/04/b1a8da7072510f611cf02388/potretpendidikan-indonesia-statistik-pendidikan2016.html

2. Ministry of Health Republic of Indonesia. 2015 Indonesia Health Profile. Available from:

http://www.depkes.go.id/resources/downl oad/pusdatin/profil-kesehatan

3. Stanhope M, Lancaster J. Public Health Nursing: Population-Centered Health Care in the Community. 9th edition. Elsevier Health Sciences. 2015.

4. Allender JA, Rector C, Warner KD. Community \& public health nursing: promoting the public's health. Philadelphia: J.B. Lippincot. 2014. 
5. Adliyani N. Maintain individual behavior towards healthy living. Lampung Medical Faculty 2015; 4: 109-14. Retrieved from: jukeunila.com/wpcontent/uploads/2015/11 /109-114-zaraz-ona.pdf.

Publication of the Manuscript accessed April 11, 2018.

6. Nicholson JA, Naeeni M, Hoptroff $M$, Matheson JR, Roberts AJ, Taylor D, et al. An investigation of the effects of a hand washing intervention on health outcomes and school absence using a randomised trial in Indian urban communities. Tropical Medicine and International Health 2014; 19(3), 284-92.

https://doi.org/10.1111/tmi.12254

PMid: 24382344

7. Depok City Health Office. Depok City Health Profile in 2014. Depok: Depok Health Office. 2015.

8. Technical guidelines for clean and healthy behavior (PHBS) in the school order. Depok: Depok City Health Promotion Section. 2016.

9. Health Research and Development Agency. 2013 basic health research (Riskesdas). 2013 National Report, 1-384. 2013. http://doi.org/1 December 2013

10. Stanton-Chapman TL, Brown TS. Promoting positive peer interactions in the preschool classroom: the role and the responsibility of the teacher in supporting children's sociodramatic play. Early Childhood Education Journal 2015; 43:99-107. https://doi.org/10.1007/s10643-014-06358

11. Thibodeau RB, Gilpin AT, Brown MM, Meyer BA. The effects of fantastical pretend-play on the development of executive functions: An intervention study. Journal of Experimental Child Psychology 2016; 145: 120-38. https://doi.org/10.1016/j.jecp.2016.01.001 PMid: 26835841

12. Purnami, N.K.T, Garminah, N.N., Sudarma, I. K. Effect of sociodrama method assisted by folklore on the speaking skills of fifth grade elementary school students. PGSD pulpit e-Journal University of Education Ganesha PGSD Department vol 2 no: 1. 2014. Retrieved from:
ejournal.undiksha.ac.id/index.php/JJPGS

D/article/view/1959.

The Publication Manuscript was accessed on April 11, 2018

13. Ghimire S. A study to assess the effectiveness of game- based learning on knowledge regarding the healthy dietary pattern among the school children in selected government schools, Bengaluru, Asian Journal of Nursing Education and Research 2016; 6(1): 133-7.

https://doi.org/10.5958/23492996.2016.00 026.4

14. Ejike CU, Oluwole AS, Mogaji HO. Development and testing of Schisto and Ladders $^{\mathrm{TM}}$, an innovative health educational game for control of schistosomiasis in schoolchildren. $B M C$ Research Notes 2017; 10: 236. https://doi.org/10.1186/s13104-017-25455

PMid: 28659195 PMCid: PMC5490240

15. Fitriani, D. Effect of peer education on clean and healthy behavior (PHBS) on the aggregate of school-aged children at risk of worms in Baru Village, Manggar Belitung Timur District. (No Thesis Published) Depok: FoN UI. 2011

16. Profile of SDN Curug 2, 3, 4 schools and MI Al Islam. Depok: 2017

17. Kusumawardani LH, Mulyono S, Fitriyani P. Increased diarrhoea prevention behaviour through playing socio-drama therapeutics. Thesis: Not Published. Depok: FIK UI. 2017

18. Hockenberry MJ, Wilson D. Wong's essentials of pediatric nursing. St. Louis: Mosby Inc. 2009.

PMCid: PMC3928629

19. Sare MV, Ogilvie L. Strategic planning for nurses change management in health care. Massachusetts: Jones and Bartlett Publishers. 2010

20. Pender N, Murdaugh C, Parsons MA. Health promotion in nursing practice. Seventh Edition. Sidney: Appleton \& Lange. 2011.

21. Wahed T, Shah S, Kaukab T, Saha NC, Khan IA, Khanam F. Knowledge of, attitudes toward, and preventive practices relating to cholera and oral cholera 
vaccine among urban high-risk groups: findings of a cross-sectional study in Dhaka, Bangladesh. BMC Public Health 2013; 13, 242.

https://doi.org/10.1186/1471-2458-13-242 PMid: 23509860 PMCid: PMC3608226

22. Apriany, D. Differences in handwashing behavior before and after being given health education to children aged 4-5 years. 2012. Sudirman Nursing Journal (The Sudirman Journal of Nursing), Volume 7, No.2, July 2012, 7 (2). The Publication Manuscript is accessed April 11,2018 .
23. Wahyuni, S. Effect of behavior modification by modeling techniques on handwashing behavior in school-age children in Sukowono District, Jember Regency. Thesis: Not published. Depok: University of Indonesia. 2016 